\title{
Political leadership and conflict resolution: An African example
}

\author{
Wallace Warfield and Ashad Sentongo*
}

\begin{abstract}
Challenges to post-conflict leadership in African states highlight the need for democratic capacity building, with clear participatory processes involving communities and the leadership as a necessary condition to mitigate new or resurrected conflicts. This article explores transformational leadership and how it relates to democratic capacity building in Rwanda. We argue that community capacity building through grassroots leadership is a necessary and sufficient ingredient for the development and sustenance of democracy in postconflict societies. Reconciliation through justice, political reforms including decentralisation, and women's empowerment as critical variables in this process characterise a transformational agenda to gradually achieve stability at the grassroots. Despite dilemmas of justice and democracy, transformative leadership in Rwanda continues to evolve at both state and grassroots levels through processes based on indigenous knowledge and practices like gacaca and ingando to achieve the greater good of reconciliation.
\end{abstract}

* The late Dr Wallace Warfield was Associate Professor at the School for Conflict Analysis and Resolution (S-CAR), George Mason University, Arlington, VA.

Mr Ashad Sentongo is a Ph.D. Candidate at the School for Conflict Analysis and Resolution (S-CAR), George Mason University, Arlington, VA. His research focuses on power-sharing and ethnic conflict in African states. 


\section{Political leadership and conflict resolution: An African example}

\section{Introduction}

Gardner (1990:1) defines leadership as 'the process of persuasion or example by which an individual induces a group to pursue objectives held by the leader or shared by the leader and his or her followers'. In the African context, it was often the case that post-independence national leadership was of the so-called 'big man' style. In this form of leadership, decision making over the distribution of resources, power, and authority was (and still is to a limited extent) exclusively controlled by the president. To the extent that objectives were participatory, state leaders mainly involved a tightly controlled group of political elites.

In the dawn of the $21^{\text {st }}$ century, the emerging African paradigm reflects a need for democratic capacity building - one that invites diverse communities into a participatory process with leadership. When we speak of diverse communities, we address not so much ethnographic communities (although these are relevant) as we do class communities - in the knowledge that class divisions on the continent create resource-controlling elites. In this context, inter-ethnic grassroots communities remain disenfranchised, becoming the source of new or resurrected conflicts.

If the $21^{\text {st }}$ century African leader (and here we flatten the definition to include a range of leadership at different levels in society) is to stimulate democratic capacity building in communities, this individual must first learn the process of managing or mitigating conflict to build a community's capacity for sustainable peace and development. Burns (1978) recognised that leadership emerges in response to conflict. Indeed, one could argue that conflict gives depth and perspective to leadership. ${ }^{1}$ In the African context, this refers not only to the typically understood intra-state conflict, but to the proliferation of conflict taking place at the local level as well. Conflict is a catalytic agent

1 There is a number of examples where leadership has created conflict so as to sustain themselves in their positions. Our focus here is not conflict manipulation by leadership for self-serving ends. Our interest is in examining leadership who see conflict as an opportunity to raise the consciousness and epistemology of a society. 
for transformation, and conflict mitigation is the tool that negotiates this transformation.

In this article we explore the nature of transformational African leadership in relation to democratic capacity building, focusing on Paul Kagame, President of Rwanda. We begin with a broad view of African democracy and of how leadership has shaped this phenomenon to respond to the needs of the political state. Then, exemplifying Rwanda, we move to an argument that community capacity building through grassroots leadership is a necessary and sufficient ingredient for the development and sustenance of African democracy. To do so, transformational leadership must exist at various levels of the state in order to mobilise community consciousness. We look at reconciliation through justice, political reforms including decentralisation, and women's empowerment as critical variables in this process, noting the conditions of implementation that create space for levels of leadership to execute a transformational agenda. In doing so, we comment on the tension between justice and democracy and the dilemma these two political concepts pose for a transformational leader such as Paul Kagame.

Lederach (1997:38-39) provides a model of how one can examine leadership at various levels, ranging from top level to leadership at the grassroots. Lederach envisions three levels of leadership. At the top (Level 1) are the regime elites, politicians, religious leaders, and the military who engage in highly visible negotiations at the state level. At Level 2, Lederach locates intellectuals, ethnic leadership, regional or local religious leaders, and heads of recognised nongovernmental organisations (NGOs). These are individuals who are most likely to be engaged in negotiations with Level 1 over the implementation of national policy. Such was the case in Rwanda where individuals who headed up humanitarian organisations were involved with Level 1 in the implementation of gacaca and ingando programmes, as part of the national reconciliation programme. We will be discussing this at length later in the paper. Level 3 is where the grassroots leadership resides. Here we find indigenous community leaders of one sort or another who tend to be engaged in the struggle for bringing more resources to their local population. Of course, these are not rigid divisions. In some post-conflict developing countries there is mobility 


\section{Political leadership and conflict resolution: An African example}

as some Level 2 actors will be pulled into Level 1 and Level 3 actors can move to Level 2.

While Lederach's attention is focused on third party interventional analysis, his model becomes an excellent vehicle to describe the gap between how democracy is interpreted and how transformative leadership evolves at the state and the grassroots level. We do this via a case study of Rwanda, showing how transformational leadership following the 1994 genocide is stimulating community capacity building. In Rwanda, democracy, rather than remaining in the realm of abstract ideas, takes on a practical function of helping the state to survive.

\section{African transformational leadership}

Gardner (1990) distinguishes between transactional leadership and transformational leadership. In transactional leadership, a leader engages in an exchange process. As Koerner and Bunkers (1994:71) note in citing Burns (1978), there is an 'exchange of valued things'. The leadership process is essentially deal-making guided by the satisfaction of mutual interests through distributive gains. In the classic negotiations schema, this works well when both parties enjoy a rough symmetry of power. However, in many intrastate interactions involving regime and local actors, this is not the case. In the African context, transactional leadership often becomes the fulcrum for tension and unrest, leading to conflict. ${ }^{2}$

Distinctively, Burns (1978:20) notes that transformational leadership occurs 'when one or more persons engage with others in such a way that leaders and followers raise one another to higher levels of motivation and reality'. In this way, transformational leadership involves innovation, change, growth, and empowerment of self and others. Characteristic of this form of leadership, community leaders and followers have similar objectives and needs. A mutual sense of security, identity, recognition, development, and self-actualisation shape the contours of negotiation for change.

2 Note the Democratic Republic of the Congo (DRC) 


\section{Wallace Warfield and Ashad Sentongo}

In the African context, it is not possible to talk about transformational leadership divorced from the emergence of democracy. African democracy has been developing since the early 1990s although its transition from dictatorial, 'big man' regimes has been erratic. The current positional jockeying for power in Zimbabwe stands as a good example. Guinea Bissau and Gabon provide two more examples of democracy being thwarted by authoritarianism. Having said that, there can be little argument that a 'second independence' (Joseph 1997) is moving cautiously through the continent. The hallmark of this transition, of course, was the release of Nelson Mandela in 1990 after 27 years in prison and the negotiated end to the apartheid regime in South Africa.

Guiding the modern African state can be framed as a tension between constitutional democracy and utilitarian democracy. The latter is where democracy is interpreted and implemented on the ground in local communities. Utilitarianism can trace its origins to early Greek thought, but the first modernist expression came from Jeremy Bentham who had the idea that the morality of a social contract between a government and its people was determined by whether it provided 'the greatest good for the greatest number of people' (Ebenstein and Ebenstein 1991:596). John Stuart Mill, a libertarian, advanced this philosophic principle, pointing out that the state was no greater than the individuals who composed it (Ebenstein and Ebenstein 1991:630). From this perspective, the normative value of democracy cannot be taken for granted, but depends on the way democracy is utilised. Thus, the ethic of procedural equality comes into play. Procedural equality is about the distribution of scarce resources and decision-making across competing groups, but more importantly, it is about power. As Key (1958:5) put it, power

'... [is] fundamentally of relationships of superordination and subordination, of dominance and submission, and the governors and the governed'. Thus, utilitarian democracy has as one of its chief objectives the distribution of state power away from dominance by elites at Level 1 in the Lederach model to greater inclusivity of actors at Levels 2 and 3 (grassroots). Conflict resolution has the potential for levelling the power playing field by giving visibility to narratives embedded in local communities that are essential to the resolution of conflict and the implementation of procedural democracy. 


\section{Brief background on Rwanda}

The 1994 civil war and accompanying genocide devastated the country, with an unprecedented death toll of close to one million Tutsis and moderate Hutus, leaving thousands of orphans, disabled people, and widows. Half the population fled the country including professionals, and $80 \%$ of domesticated animals were killed. Political and economic structures and infrastructures had to be restarted. In a country with more than $85 \%$ of the population living in abject poverty, approximately 3,5 million refugee returnees and more than one third of households headed by females or orphans were threatened by HIV/ AIDS partly because of widespread rape. However, the extent of achievement in transforming relationships, institutions and communities following the genocide presents a learning opportunity on the nature and role of leadership capacities in transcending selfish and short-term goals, towards a higher order of collective gain and national stability. Many post-civil war countries continue to struggle to determine this role, and how leadership capacities interact with attitudes and institutions in such a setting to cause the desired transformation.

Daunting challenges of national reconstruction and reconciliation in postgenocide Rwanda persist, and many gains have not come without contest and discontent from various political circles within and outside the country. Central to this debate is the tension between constitutional democracy as enacted by African state elites and preferred in the broader international community, ${ }^{3}$ and what as we noted earlier can be called utilitarian democracy, which is people-oriented and seeks to involve grassroots leadership in a more inclusive and participatory manner. As a constitutional democracy, Anastase (2005) notes that Rwanda, throughout its constitutional history, never had a constitution responding to its own expectations as a nation, but often copied the constitutions of foreign countries. In doing so, the realities of political life as played out by the majority were ignored to satisfy the interests of the few.

3 Constitutional democracies are based on an inherent presumption of stability. In the African context, this model frequently produced a fraudulent electoral process that sustained a ruling regime. See Kalu 2009:9-39. 


\section{Wallace Warfield and Ashad Sentongo}

In May 2003, 90\% of Rwanda's citizens supported a new constitution for their country, which was eventually promulgated in June 2004. As Anastase further noted, the new constitution was guided by the country's context and challenges. It aims to create equitable power sharing, establish the rule of law to improve people's social justice and welfare, and establish a pluralist democratic system. It further seeks to combat the ideology of genocide in its various manifestations and to eradicate identity-based divisions by promoting national unity, ethnic and gender equality of all Rwandans, and engage in the quest for solutions through dialogue and social consensus.

As noted above, utilitarian democracy takes this approach further, viewing these aims through state actions that add value to the quality of life and maximise the effectiveness of systems and institutions to meet the needs of its citizens. Equally, a number of transformations and reforms involving community, civil society and national level stakeholders and other actors in Rwanda reflect a dominant utilitarian approach to leadership and progress in the country. According to a 2005-2007 Social Cohesion survey conducted by the National Unity and Reconciliation Commission (NURC), 97\% of those who responded from all 416 administrative sectors in Rwanda agreed that the government is doing its best to improve the standards of living. Institutional and policy reforms, aided by various conflict resolution approaches have helped to bring about a closer relationship between the two forms of democracy. While time will be the final arbiter, it is possible to say that Kagame has been comparatively successful in managing the tension between the two forms of democracy - in contrast with many other African countries. We can think of this as a politics of incorporation where political pluralism takes the form of ongoing negotiations. This is particularly notable considering that in the past decade, the country has moved from short-term recovery to more long-term and strategic macroeconomic stabilisation and diversification, decentralised governance and other extensive reform initiatives in remarkable proportions (Kanyarukiga et al. 2006).

While there are claims of increasing authoritarianism on the part of government, the leadership in Rwanda can be perceived as progressively developmental, moving steadily (albeit with a few hic-ups) on a path to sustainable long-term 


\section{Political leadership and conflict resolution: An African example}

development (Hayman 2007). The 2007 Social Cohesion survey also showed that the majority of Rwandans believed in the effectiveness of the central government, with $56 \%$ of respondents agreeing that decisions that affect communities should be left to the government.

Dorman (2006), explaining 'post-liberation' state behaviour, outlines characteristics that are applicable to Rwanda despite a history of violence, namely, amongst others: a strong government, introduction of distinctive institutional reforms, and rebuilding the nation with emphasis on security and national unity. While the methodology has invoked criticism from some quarters, the issue is whether Kagame's leadership bears utilitarian qualities that have translated into additional value in service delivery and the quality of life among the citizenry. For example, according to the United Kingdom's Department for International Development (DFID), Rwanda is working within a structured development framework towards a long-term vision via a poverty reduction strategy bolstered by a strong political commitment from the government (Kanyarukiga et al. 2006).

Genocide experiences provide the over-arching framework within which all these efforts take place and its legacy predisposes some of the priorities in the country's policy processes. Underneath, as Evans et al. (2005) note, is a leadership considered to be genuine in its commitment to socio-economic development as well as good governance, even if it diverges in some respects from western norms.

Following, we exemplify transformational leadership and utilitarian democracy by discussing how Rwanda approaches political reforms, reconciliatory justice, and women's empowerment. While these do not suggest the absence of inter-group differences in a post-conflict setting, they contribute greatly to socio-political transformations necessary for peace and reconciliation.

\section{Political reforms}

Post-conflict political reforms are critical to restore integrity, stability and reconciliation. Reform creates the opportunity for new roles and responsibilities to emerge and challenge various aspects of the preceding 


\section{Wallace Warfield and Ashad Sentongo}

political order. Webley (2004) highlights the ongoing debate that locates Rwanda's predisposition to the 1994 genocide in different political orders in the country's history, for instance, the pre-colonial conquest of Hutus and Twa by Tutsi, European colonial rule and state structure, and the pre-genocide government of Habyarimana blamed for the collapse of the 1994 Arusha Accord. Mamdani (2001) argues that these different orders have over the years been more often defined in terms of power struggles to access political and economic opportunities. Political reform in Rwanda has emphasised transformation of systems and structures to expand political inclusion, especially through political party activity, and decentralisation of power through local governments to communities. According to the 2007 survey, 91\% of Rwandans believed that they take part in decisions that affect them through established political processes.

Decentralisation of governance (decision-making, fiscal and financial planning and management) to provincial and local levels, and multiparty politics are some of the major political reforms in the country. Respectively, they both engage levels 1, 2 and 3 in the Lederach model and combine two other theoretical models that support this approach to power-sharing in ethnically segmented societies: the consociation model (Lijphart 1968, 1977), and the integrative model (Horowitz 1985). Lijphart emphasises the need for proportionality in government and segmented autonomy in combination with a high degree of self-governance (decentralisation). Horowitz also suggests dispersion of territorial power to take the heat off of a single focal point, and policies to promote moderation, such as electoral laws that encourage preelection coalitions and alliances in a multiparty setting. Both approaches seem to draw on the logic of 'contact hypothesis' (Allport 1954, Brewer 2000), the idea that prejudice and discrimination can be reduced by contact between parties under conditions that promote equal status. Political reforms in Rwanda seem to reflect these theoretical models through decentralisation and political pluralism.

In 2001, Rwanda held the first local government elections, under the new policy to decentralise governance. Among those elected nationally were 2765 local council representatives, 106 town and district mayors, and an 


\section{Political leadership and conflict resolution: An African example}

additional 424 new town and district executives. The real achievement of the electoral process was the fact that a new leadership was identified at all levels of society and elected. The process of decentralisation has been instituted with numerous adjustments. These include the formation of Community Development Committees (CDCs) and the Rwanda Association of Local Government Authorities (RALGA) to oversee and advise on decentralisation and other policies, and conduct training to improve leadership and decisionmaking capacities at the local level. Decentralisation also remains the principal gateway for citizens to decide and elect leaders of their preference and influence agendas for local governance and development. Local governments now undertake growth and development work previously handled by the central government, including access to education, health, poverty alleviation, dispute resolution, local elections, and other social and institutional programmes.

The challenges to decentralisation of governance notwithstanding, the 20052007 Social Cohesion survey showed that ' $70 \%-85 \%$ of respondents agreed that the decision-making bodies created through decentralized processes are knowledgeable, autonomous in their decision making and work well together' Further, many agree that decentralisation has contributed to an improvement of civil society. For example, $41 \%$ of respondents belong to saving and credit associations. This has not come without discontent from the political opposition and allies of the Hutu rebels, now reorganised in the Democratic Republic of the Congo. Still, decentralisation of power to local governments presents a transformative opportunity that seeks to unite the country, with a large portion of the population that has remained traumatised.

Kagame's resoluteness, given the need to rid the country of conditions that occasioned genocide, has been most visible in reforms to expand space for political participation while guarding against any recourse to pre-genocidal and genocidal practices. Unlike the traditional majoritarian 'winner-takes-all' approach to governance, Andrew England (2006) reports that Rwanda's politics runs on a consensual basis, with all parties represented in government, and according to the 2003 constitution, even the party with a majority of deputies cannot hold more than $50 \%$ of cabinet posts. Fluid as it may appear, such increased inclusiveness and participation in decision-making processes and 


\section{Wallace Warfield and Ashad Sentongo}

implementation of programmes in which communities have specific needs are central to stability in post-conflict societies.

The government is also changing genocidal narratives at the national and grassroots levels, focusing on ethnic cooperation and unity, including efforts to make the whole population trilingual in Kinyarwanda, French and English. Kanyarukiga et al. (2006) have argued that this will ultimately help Rwanda to overcome historical linguistic and cultural divides, central to the country's power and ethnic conflicts. The government's anti-segregation ('Barwanda') policy underscores this initiative, designed to head off attempts to divide the population along ethnic lines that could threaten a return to genocide.

Many argue that ethnicity in Rwanda is more about class than language and cultural identity, largely because Rwandans are indistinguishable. Yet these factors are central in the debate seeking to locate predispositions that occasioned such a violent history, and efforts to defuse them. The above political developments, still unfolding, have facilitated individuals, families and communities to participate in judicial and women's empowerment processes and programmes, as critical aspects in transformational leadership and utilitarian democracy. However, it is paramount that Rwanda's leadership at all levels need to de-construct associated conflict narratives, and construct a new discourse to guide the ongoing reconciliation and transformation.

\section{Reconciliation through justice}

Through gacaca and ingando, the leadership tapped into indigenous customs and norms to complement traditional western models and mechanisms to achieve reconciliation through justice. Countries that have gone through devastating wars, for example, Liberia and the former Yugoslavia, often singled out perpetrators of crimes and violence on the assumption that justice is done by apprehending them. As Hayman (2007) argued, from the perspective of many, the transformation and reduction of tensions in Rwanda needed a pragmatic approach emphasising reconciliation, and working in concert with a retributive justice system favoured in western norms to bring key actors to trial. Rwanda's approach has combined levels 1, 2 and 3 of the Lederach model, 


\section{Political leadership and conflict resolution: An African example}

drawing from international systems and norms to establish a National Unity and Reconciliation Commission (NURC) on the one hand, and a moderated local approach at the national/communal level through the gacaca and ingando systems on the other. Despite the unevenness of these mechanisms, many communities have experienced a measure of justice and reconciliation, without undermining mainstream western-based approaches to justice in post-conflict situations.

\section{Gacaca: Reconciliation and justice}

Endogenous mechanisms of justice, rooted in local community customs gain their preference in responding to local conflicts because they evolve and are practised for extended periods rather than being imposed or imported into societies (Zartman 2000:7). Lederach (1995:10) has also argued that 'understanding conflict and developing appropriate models of response necessarily needs to be rooted in [the ethnology of a community] and must respect and draw from the cultural knowledge of a people'. The government decision to formalise, moderate and improve gacaca highlights level 3 of the model as a major component of justice and reconciliatory processes across communities.

'Gacaca' is originally a traditional community-based approach to dispute resolution, conducted by elders in predominantly informal settings on issues such as land, theft, marriage, and property. The practice has been in place in major parts of the country since pre-colonial days. In 2002, the Kagame regime adopted gacaca to try lesser crimes of genocide, as an additional layer to provide local justice and involve local communities in the reconciliation process. It operates alongside the national court system and the International Criminal Tribunal for Rwanda, and at the local, sector, district and province levels of the society. The main feature of the system is the traditional weekly meetings. These serve as local courts, and have been used to handle a number of genocide related cases at the local level. Community members meet on a weekly basis to collectively consider cases and other issues of dispute in the 


\section{Wallace Warfield and Ashad Sentongo}

community, to give evidence and testimony for the elected judges to render their judgement on the matter.

Intended to provide relief to an overwhelmed justice sector with thousands of prisoners who could potentially stand trial, gacaca became a visionary approach to draw grassroots communities into the work of the NURC, but also complement other national efforts to address the legacies of genocide. To date, the gacaca system celebrates its contribution to a high level of awareness about the rule of law at the grassroots, and justice through public testimonies and confessions. The Center for Communication Programs (2001) reported that $90 \%$ of the population knew about gacaca and the reconciliation process through election of judges, talk shows, sports competitions, music and drama, and the print media. According to the Social Cohesion survey (National Unity and Reconciliation Commission 2008), 96\% of survivors and $83 \%$ of prisoners believed the gacaca system was a better way of dealing with their cases than traditional courts as a way to eradicate impunity. Some NGOs have noted, however, that the real indicator of people's response to and embrace of gacaca is not what they say to surveyors and pollsters, but whether they show up at the weekly gacaca meetings in their communities (Webley 2004).

The system operates in 12103 cell-level courts across the country, each conducted face-to-face by 169442 inyangamugayo (persons of integrity) as judges elected by local communities and then trained by government (Huyse and Salter 2008:41). While the courts are criticised for lack of fair international trial standards, government argues that 'their fairness could be ensured by the participation of the local population' (Amnesty International 2010:12), yet they also helped to expedite delivery of justice in ways that the majority of the people understood and culturally identified with. From January 2006 to February 2007, a total of 71405 were tried, 33233 sentenced to prison, 16438 put on community service, 15219 acquitted, and 72000 appeals were dealt with (Huyse and Salter 2008:43).

This bottom-up approach to redress the legacies of genocide has empowered grassroots leadership to take charge of the local reconciliation process (as they understand it), and offer better utility in moving victim communities 
past their grief. Alana Tiemessen (2004) goes on to note that gacaca was resurrected because the cultural norms of international justice have proven to be inadequate to promote reconciliation in post-genocide Rwanda, and critical support from the international community must generate a way of retaining gacaca's indigeneity without serving the interests of political regimes or inciting ethnic tensions.

\section{Ingando: A traditional reflective practice}

Nantulya and Alexander (2005) report that ingando is a Rwandese traditional practice of immobilising regular activities to reflect and find solutions to communal challenges, and the re-integration of convicts into communities through special programmes. In pre-modern times, traditional kings, their armies and community leaders mobilised their subjects to come together and reflect on situations like wars, droughts, diseases and other calamities, and to find collective solutions. With support from the government, NURC revived the practice of ingando to engage convicts and communities in reconciliatory dialogue. As a complement to gacaca, the objective of ingando is to transform relationships from conflict into peaceful coexistence at individual and communal levels. Looked at from a utilitarian perspective, ingando has the capacity to address the greater good implicit in level 3 of the Lederach model.

Initially, ingando participants retreated into residential programmes of between three weeks and two months, to reflect on their crimes and other atrocities and to commit themselves to ways of ensuring that crimes do not re-occur. Themes covered include analysis of Rwanda's problems, history of Rwanda, political and socio-economic issues, rights, obligations, duties, and leadership. It is mandatory for prisoners to participate in this programme before they are released back into their communities. By 2005, 102909 people (released prisoners, perpetrators, local and community leaders) have been trained (Nantulya and Alexander 2005). To date, the programme takes the form of civic education and has been extended countrywide to also include students, traders, women, youths, leaders and perpetrators of genocide and other crimes. NURC, working through local councils, schools and other community structures, provides logistics and other forms of support. 
Approximately 3000 students attend ingando retreats each year, mostly at the National Ingando Centre in Ruhengeri.

As integrative and indigenous mechanisms, gacaca and ingando demonstrate a unique perspective to approach leadership in post-conflict societies. They exemplify transformation and a utilitarian approach based on consilience or unification of knowledge (Wilson 1998:11), i.e. integrating state processes with local traditions to achieve local peace and national stability. The utilitarian value of the leadership in Rwanda manifests in the recognition of widely acceptable traditions and readily available local capacities. These are legislatively integrated within systems of the state and transformed into institutions to generate reconciliation and accelerate development, yet they remain culturally relevant and meaningful to the everyday life of people at communal level. Therefore, while gacaca takes a judicial approach to enable individuals and communities to account for crime and violations, ingando provides opportunities for reform and reintegration and the enabling environment for this to occur.

\section{Women's empowerment}

The social and political roles of women are critical to post-conflict stability and reconciliation. In Rwanda a number of women play prominent roles in judicial, reconciliation and reconstruction processes, which demonstrates a remarkable transformation and improvement in their status in the culture and institutions of the state. Powley (2004:5) explains that 'genocide was committed most heavily upon men, and women by their demographic majority took on multiple responsibilities to rebuild their families and the society'. Many women played critical roles to organise new communities following the genocide, providing resources and other services to meet the needs of victims and survivors. Others single-handedly catered to the needs of families, and found homes for orphans. The restorative role of women in post-conflict Rwanda was (and still is) supported in part by public and private organisations. Most importantly at the policy level, the presence of many women within government '.. has contributed to progressive gender policies within the administration' (Powley 2004:7). Reflecting once again 


\section{Political leadership and conflict resolution: An African example}

on the Lederach model, women in Rwanda play critical roles at all levels of leadership.

Historically, women have not faired well in constitutional democracies. ${ }^{4}$ The Schumpeterarian (Schumpeter 1950) emphasis on voting (until recently upheld in western democracies) has favoured the embedded power of men. ${ }^{5}$ As political actors at Level 1, Rwandan women play a central role in the governance, reconciliation and reconstruction of the country. They are constitutionally guaranteed 24 of the 80 deputies, and $30 \%$ of the senate. In the 2003 legislative elections, women won $40 \%$ of the seats in the chamber. By 2007, there were 9 women in the 26-seat Senate and 38 women in the 80 -seat Chamber of Deputies. Nine women also occupied cabinet positions. Extending the input of women in national, regional, and community administration, the country's policy framework assures that as part of the decentralisation of power, one third of executive administrative positions in local government are held by women. To date, women occupy 56\% of seats from the September 2008 parliamentary elections (United Nations Development Fund for Women 2008). The potential for women's political empowerment is supported by empirical data that show that as the representation of women increases in representative bodies, so does the legislation that speaks to their needs (Dowding, Godin and Pateman 2004:23). Joseph Sebarenzi, former Speaker of the Parliament, recognises that 'gender representation in Rwanda is an undeniable fact and the government should be credited for it' (Powley 2004:6).

Strong perceptions that disfavour women persist however, and women remain vulnerable to the effects of poverty and other cultural and institutional arrangements that still favour males. Sexual and other forms of abuse and discrimination against women, entrenched over the years in social and cultural systems, continue to challenge the leadership in Rwanda especially when they are wrapped in silence. Many women still need to gain leadership experience after years of discrimination, to learn how to articulate their rights

\footnotetext{
4 See, for example, Lipset 1990:188-189.

5 This was particularly true during the heyday of political machines in a number of cities in the United States. See, for example, Erie 1988.
} 


\section{Wallace Warfield and Ashad Sentongo}

and opinions, and how to balance these roles as mothers or family heads faced with strong cultural obstacles. Drawing from Mamdani's (2001) analysis of cultural and political identities in pre- and post-colonial Rwanda, there has been a remarkable transformation of social and political structures that in the past held women in Rwanda passive and insignificant. He states that in the past families and communities maintained a patriarchal approach to build social relationships and structure political institutions. The current outlook of women's involvement in government and the roles they play at national, village and family levels demonstrate a leadership environment that had enabled transformation of such traditions to occur.

To deal with taboos and other hindrances to women's empowerment, a Ministry for Gender, and the National Women's Council were set up in 1995 to ensure their participation even at the lowest village level of leadership (Umudugudu). This is evidenced even in critical sectors like security, where Powley (2004) reports that women have made great contributions. For example, in northern and northwestern Rwanda (Ruhengeri, Gisenyi, and Kibuye provinces), women have been instrumental in stabilising border communities, engaging rebels to return and reintegrate them in Rwandan society.

\section{Critique}

Critics question Kagame's style of leadership, noting that it is tainted by the arrest and imprisonment of the former President and ally Pasteur Bizimungu, banning of political parties before 2003 elections, dominating the discourse about genocide to cover up atrocities committed by the Rwandan Patriotic Front (RPF), and banning ethnically aligned political activities while maintaining a Tutsi dominated RPF Army and political party. Indeed, a hint of the dialectic haunts the leadership of Rwanda as it maintains a strong voice on its priorities and policies in areas where the government wants to achieve specific goals, all the while, pushing through political reforms and dialogue that eluded the political culture of Rwanda since independence. The 2008 parliamentary elections were held under a coalition of political parties alleged to be allied to the RPF, because other opposition parties refused to participate claiming unlevelled political space. 


\section{Political leadership and conflict resolution: An African example}

Residual ethno-political tensions have resulted in administrative and organisational challenges that tend to undermine the reconciliatory value and cultural relevance of Kagame's leadership style. Tiemessen (2004) notes that the system, marred by ethnic tensions, and because of increasing state influence in the selection of judges and general administration, is viewed by many observers to serve and perpetuate Tutsi dominance and power, and silence dissenting voices against government. Particularly, the failure to prosecute alleged perpetrators from the ruling RFP continues to fuel allegations of Hutu witch-hunting, and many Hutus have fled into the DRC and other neighbouring countries claiming persecution. This has complicated the allocation of 'victimhood' in Rwanda based on genocide and post-genocide accounts from participants in the gacaca courts. It reinforces Lerche's (2000) argument in post-conflict reconciliation that there are always competing narratives of victimhood, with all sides having their own version of the truth of 'what really happened'.

\section{Conclusion}

Transformative leadership is necessarily equated with what Greenstone and Peterson (1973) call orthodox liberalism: essentially, a broad redistribution of goods and services by the state. As we have noted in one way or another, transformative leadership has to balance constitutional democracy (often under pressure from international actors) with utilitarian democracy where needs and interests of grassroots leadership are stimulated. In this sense, transformative [political] leadership can be better described as pragmatic liberalism. Or putting it another way, pragmatic realism where procedural democracy (in this instance, the distribution of power) is occasionally sacrificed to produce the 'greater good'. Here, the Kagame regime needs to be wary of undercutting the spirit of utilitarianism by centralising key decision making and creating an illusion of grassroots participation through implementation.

The heart of the matter then, for the transformative leader attempting to establish the greater good in deep-rooted identity conflicts is reconciliation. The data on truth and reconciliation initiatives conducted after intra-state conflicts marked by opposing identity groups suggest that reconciliation is an 
uneven process at best. As we noted above in the Rwanda scenario, victims' sense of injustice does not always end at the conclusion of a gacaca hearing. Victims often experience expressions of regret and feel that entreaties for forgiveness are insincere. Or that the retributive justice calculus (where it is in place) does not match the atrocity of the crime. (Avruch and Vejarano 2002; Kriesberg 2003).

In writing about the seemingly alchemic mixture that is producing Rwandan governance, our observations should not be taken as a prescription that sacrifices inherent values of constitutional democracy on the altar of pragmatic realism. Constitutional democracy should have a normative goal of responding to the needs of all who live within its reach. Our emphasis is on the transformative leader who acknowledges the tension, but also the opportunities existing in a broadly participatory political process. Such a leader values the role conflict mitigation can play in managing this tension and building a nation's capacity for sustainable peace and development.

\section{Sources}

Allport, Gordon W. 1954. The nature of prejudice. Reading, MA, Addison-Wesley Publishing Company.

Amnesty International 2010. Safer to stay silent: The chilling effect of Rwanda's laws on 'genocide ideology' and 'sectarianism' Index: AFR 47/005/2010. August 2010. London, Amnesty International. Available from: <http://www.amnesty.org/en/library/info/ AFR47/005/2010/en>

Anastase, Shyaka 2005. The Rwanda conflict: Origin, development, exit strategies. A Study ordered by The National Unity and Reconciliation Commission. Available from: <http:// www.nurc.gov.rw/index.php?option $=$ com_content\&view=article\&id $=63$ :the-origin-ofrwandan-conflict\&catid=35:researches\&Itemid=40>

Avruch, Kevin and Beatriz Vejarano 2002. Truth and Reconciliation Commissions: A review essay and annotated bibliography. Social Justice, 2 (1-2), pp. 47-108. (Republished in The Online Journal of Peace and Conflict Resolution, 4 (2), Spring 2002. Available from: $<$ http://www.trinstitute.org/ojpcr/4_2recon.htm>)

Brewer, Marilynn B. 2000. Superordinate goals versus superordinate identity as bases of intergroup cooperation. In: Capozza, Dora and Rupert Brown eds. Social identity processes. London, Sage.

Burns, James McGregor 1978. Leadership. New York, Harper and Row. 


\section{Political leadership and conflict resolution: An African example}

Center for Communication Programs 2001. Perceptions about the Gacaca Law in Rwanda: Evidence from a multi-method study. Baltimore, MD, Johns Hopkins University.

Dorman, S.R. 2006. Post-liberation politics in Africa: Examining the political legacy of struggle. Third World Quarterly, 27 (6), pp. 1085-1101.

Dowding, Keith, Robert E. Godin and Carole Pateman 2004. Justice and democracy: Essays for Brian Barry. Cambridge, Cambridge University Press

Ebenstein, William and Alan O. Ebenstein 1991. Great political thinkers: Plato to the present. Chicago, Holt, Reinhart and Winston.

England, Andrew 2006. Rwandan politics: Designed to avoid extremism. Financial Times, 4 December 2006.

Erie, Steven P. 1988. Rainbow's end: Irish Americans and the dilemmas of urban political machines, 1840-1985. Berkeley, University of California Press.

Evans, Alison, Laure-Hélène Piron, Zaza Curran and Ruth Driscoll 2005. Independent evaluation of Rwanda's Poverty Reduction Strategy 2002-2005 (PRSP1). Final Report February 20. London, Overseas Development Institute (ODI) and Brighton, Institute of Development Studies (IDS).

Gardner, John W. 1990. On leadership. New York, Free Press.

Greenstone, David J. and Paul E. Peterson 1973. Race and authority in urban politics. New York, Russell Sage Foundation.

Hayman, Rachel 2007. Milking the cow: Negotiating ownership of aid and policy in Rwanda. Global Economic Governance Programme (GEG). University College, Oxford. Working Paper 26.

Horowitz, Donald 1985. Ethnic groups in conflict. Berkeley, University of California.

Huyse, Luc and Mark Salter 2008. Traditional justice and reconciliation after violent conflict: Learning from African experiences. Stockholm, International Institute for Democracy and Electoral Assistance (IDEA).

Joseph, Richard 1997. Democratization in Africa after 1989: Comparative and theoretical perspectives. Comparative Politics, 29 (3), pp. 363-382.

Kalu, Kelechi A. 2009. Resolving African crises. African Journal on Conflict Resolution, 9 (1), pp. 9-39.

Kanyarukiga, Sam, Esther van der Meer, Maria Paalman, Derek Poate and Ted Schrader 2006. Evaluation of DFID Country Program - Country study: Rwanda 2000-2005. London, Department for International Development (DFID).

Key, V.O. Jr. 1958. Politics, parties, and pressure groups. New York, Thomas Y. Crowell.

Koerner, Joellen Goertz and Sandra Schmidt Bunkers 1994. Transformational leadership: The power of symbol. In: Hein, Eleanor C. and M. Jean Nicholson eds. Contemporary leadership behavior: Selected readings. $4^{\text {th }}$ edition. Philadelphia, Lippincott Publishing. 


\section{Wallace Warfield and Ashad Sentongo}

Kriesberg, Louis 2003. Constructive conflict resolution: From escalation to resolution. Oxford, Rowman and Littlefield.

Lederach, John P. 1995. Preparing for peace: Conflict transformation across cultures. Syracuse, Syracuse University Press.

Lederach, John Paul 1997. Building peace: Sustainable reconciliation in divided societies. Washington, D.C., United States Institute of Peace Press.

Lerche, Charles O. 2000. Truth commissions and national reconciliation: Some reflections on theory and practice. Peace and Conflict Studies, 7 (1).

Lijphart, Arend 1968. The politics of accommodation. Berkeley, University of California Press.

Lijphart, Arend 1977. Democracy in plural societies. A comparative exploration. New Haven, CT, Yale University.

Lipset, Seymour M. 1990. Continental divide: The values and institutions of the United States and Canada. New York, Routledge.

Mamdani, Mahmood 2001. When victims become killers: Colonialism, nativism, and the genocide in Rwanda. Princeton, Princeton University Press.

Nantulya, Paul and Karin Alexander 2005. Evaluation and impact assessment of the National Unity and Reconciliation Commission (NURC). Final Report. Institute for Justice and Reconciliation (IJR), December 2005.

National Unity and Reconciliation Commission (NURC) 2008. Social cohesion in Rwanda: An opinion survey, Results 2005-2007. Kigali, NURC.

Powley, Elizabeth 2004. Strengthening governance: The role of women in Rwanda's transitionA summary. United Nations Office of the Special Adviser on Gender Issues and Advancement of Women (OSAGI). Glen Cove, New York, United Nations.

Schumpeter, Joseph, A. 1950. Capitalism, socialism, and democracy. $3^{\text {rd }}$ edition. New York, Harper and Row.

Tiemessen, Alana 2004. Rwandan Gacaca: Competing and collaborating for justice after genocide. Paper presented at the annual meeting of the International Studies Association, Le Centre Sheraton Hotel, Montreal, Quebec, Canada. Available from: <http://www. allacademic.com/meta/p74581_index.html>

United Nations Development Fund for Women (UNIFEM) 2008. Rwandan women secure $56 \%$ of parliamentary seats in historic election result. 22 September 2008. Available from: $<$ http://www.unifem.org/news_events/story_detail.php?StoryID=736>

Webley, Radha 2004. Report on Rwanda. Berkeley, War Crimes Studies Center, University of California.

Wilson, Edward O. 1998. Consilience: The unity of knowledge. New York, Alfred A. Knopf.

Zartman, I. William 2000. Introduction: African traditional conflict medicine. In: Zartman, I. William ed. Traditional cures for modern conflicts: African conflict 'medicine'. Boulder, Lynne Rienner. 